УДК 622.276

\title{
ГЕОЛОГО-ФИЗИЧЕСКИЕ ОСОБЕННОСТИ РАЗРАБОТКИ СЛАБОКОНСОЛИДИРОВАННЫХ КОЛЛЕКТОРОВ ВЯЗКОЙ НЕФТИ
}

\author{
Ильясов Ильнур Рустамович1, \\ ilnur_ilyasov@mail.ru
}

\author{
Грачев Сергей Иванович², \\ grachevsi@tyuiu.ru \\ 1 Акционерное общество «Мессояханефтегаз», \\ Россия, 625048, г. Тюмень, ул. 50 лет Октября, 8Б. \\ 2 Тюменский индустриальный университет, \\ Россия, 625000, г. Тюмень, ул. Мельникайте, 70.
}

\begin{abstract}
Актуальность. Восточно-Мессояхское месторождение является уникальным не только по размеру геологических запасов, но и по своим геологическим особенностям. Основной продуктивный пласт ПК1-3 содержит около 65 \% запасов и представляет собой слабоконсолидированный коллектор с высоковязкой нефтью. Опыта разработки аналогичных месторождений в условиях материковой Арктики практически нет. Исследование геолого-физических особенностей разработки слабоконсолидированных коллекторов вязкой нефти является актуальной задачей.

Цель: провести анализ и выявить ключевые геолого-физические особенности разработки слабоконсолидированных коллекторов вязкой нефти для поиска методов и технологий повышения эфрфективности их разработки.

Объекты: эксплуатационные слабоконсолидированные коллектора вязкой нефти Восточно-Мессояхского месторождения. Методы: критический анализ, контент-анализ, анализ и обобщение имеющегося опыта разработки слабоконсолидированных коллекторов вязкой нефрти на примере пласта ПК 1-3 Восточно-Мессояхского месторождения.

Результаты. Проведен критический анализ результатов исследования ключевых геолого-фризических характеристик пласта ПК 1-3 и его фрлюидов, которые необходимо учитывать для его максимально эфрфективной разработки. Составлен перечень ключевых особенностей. Показано их влияние на эфффективность разработки. Проведен анализ опыта заводнения, анализ работы аквифера и его влияния на режим разработки. Доказана необходимость применения вторичных методов разработки пласта ПК 1-3 и системы поддержания пластового давления. Однако ввиду описанных выше особенностей традиционное заводнение слабоконсолидированных коллекторов вязкой нефти сопряжено с высокими рисками прорывов воды и низким коэфффициентом охвата пласта заводнением, что будет оказывать большое влияние на эфффективность разработки и конечный коэфффициент извлечения нефти. Сделан вывод об необходимости исследования альтернативных технологий и агентов заводнения слабоконсолидированных коллекторов вязкой нефти, в том числе с применением фризико-химических методов увлечения нефтеотдачи с системным подходом, что является актуальной и интересной задачей.
\end{abstract}

\section{Ключевые слова:}

Слабоконсолидированный коллектор, вязкая нефть, заводнение, геолого-фризические свойства, разработка месторождений.

\section{Введение}

Восточно-Мессояхское месторождение (ВМM) географически расположено в 340 км севернее г. Новый Уренгой на Гыданском полуострове и является самым северным разрабатываемым месторождением в России.

Основным объектом разработки ВосточноМессояхского месторождения является пласт ПК1-3, содержащий 65 \% начальных геологических запасов нефти. Продуктивные отложения пласта ПК1-3 на месторождении выделены в кровельной части песчаных отложений покурской свиты (уватский горизонт, сеноманский ярус).

\section{Обстановки осадконакопления}

Апт-альб-сеноманские отложения в пределах Восточно-Мессояхского месторождения [1] попадают в пределы Тазовско-Уренгойского литофациального района.

Отличительной особенностью отложений покурской свиты является сложность и неоднозначность корреляции отдельных пластов ввиду отсутствия вы- держанных по простиранию реперных границ внутри интервала свиты, что связано с преимущественно континентальными условиями формирования слагающих свиту отложений. Уверенными границами являются только кровля и подошва отложений покурской свиты, к которым приурочены региональные сейсмогоризонты «Г» (кровля) и «М» (подошва покурской свиты). В пределах изучаемого месторождения мощность отложений покурской свиты изменяется от 870 до $980 \mathrm{M}$.

Один из способов корреляции отложений покурской свиты [2] заключается в определении границ секвенций (сиквенсов), связанных с региональным изменением относительного уровня моря (ОУМ). Для этого предлагается использовать суммарную кривую каротажа альфа потенциала собственной поляризации (АПс), полученную путем суммирования кривых АПс отдельных скважин в изохронных границах (между сейсмогоризонтами «Г» и «М»). Полученная таким образом кривая АПс отражает глобальные изменения ОУМ, происходившие на изучаемой территории, с которыми связаны границы секвенций. 
Данный метод реализован на ВМM, на рис. 1 приведена средняя кривая АПс (нормированная кривая ПС в интервале покурской свиты имеется в наличии), полученная по всем скважинам, вскрывающим всю мощность отложений покурской свиты (большая часть фонда поисково-разведочных скважин). В интервале отложений пласта ПК1-3 ( 120 м от кровли свиты) на средней кривой АПс отмечается цикличность: резкие переходы от глинистых отложений (пониженные показания АПс) к песчаным (повышенные показания АПс) могут быть связаны с изменением условий формирования отложений (изменением ОУМ).
На основе средней кривой АПс интервал отложений пласта ПК1-3 разделен на три части, каждая из которых отождествляется с интервалами циклитов (A, В, С), выделенных ранее по литологическому признаку. Граница «кровля циклита В», отделяющая отложения приливно-отливной равнины от нижележащих отложений руслового комплекса, диагностируется уверенно по средней кривой АПс на расстоянии примерно 13 м от кровли сеномана (ОГ «Г»). Определение этой границы по отдельным скважинам в большинстве случаев уверенно, граница определена на расстоянии от 8 до 19 м от кровли сеномана, в среднем составляя $13 \mathrm{~m}$.

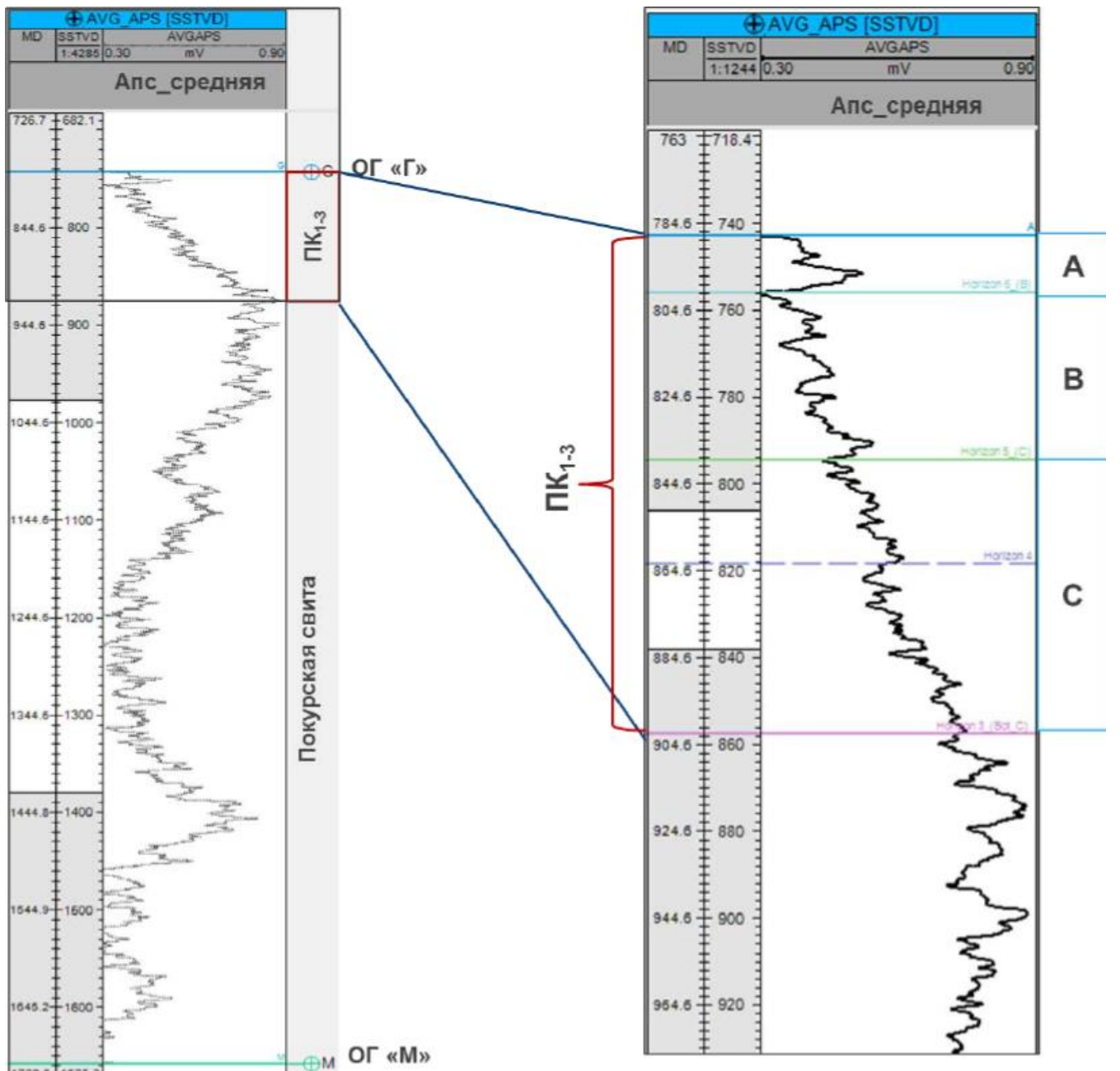

Рис. 1. Средняя кривая каротажа альфа потенциала собственной поляризации в интервале отложений пласта ПК 1-3 Fig. 1. Mean alfa spontaneous potential log in the range of PK 1-3 deposit

Несколько сложнее выглядит разделение отложений циклитов «В» и «С». Согласно средней кривой АПс граница «кровля циклита С» находится на расстоянии примерно 55 м ниже кровли сеномана и соответствует переходу от заглинизированных песчаников (пониженные значения АПс) к более «чистым» (повышенные значения АПс). Однако прослеживание данной границы в отдельных скважинах затруднительно ввиду наличия песчаных отложений циклита «В», врезающихся в отложения циклита «С». Как показывает анализ, возможны несколько видов контакта между русловыми отложениями циклитов «В» и «С»: контактные русловые отложения, неконтактные с эрозионным врезанием и без, единичные русла или полное отсутствие русловых отложений в интервале циклита «В». Сама по себе литологическая граница, отделяющая отложения с повышенными фильтрационноемкостными свойствами (ФЕС) (русловые отложения), имеет большое практическое значение - картирование наиболее высокопродуктивных отложений - поэтому разумно принять для работы именно литологическую границу, а не изохронную. Однако латеральная связан- 
ность между коллекторами определяется их первичным взаимным расположением во время седиментации, т. е. описывается изохронными границами. Учесть этот фактор можно, используя в качестве подошвы циклита «С» изохронную границу, определенную в разрезе каждой скважины с учетом средней кривой АПс (близкий к средней кривой реперный глинистый пропласток по данным геофизических исследований конкретной скважины), а разделение интервала циклита «С» на элементарные слои (нарезку) выполнить конформно подошве циклита (изохронной границе). Для интервала отложений циклита «В» изохронной границей служит кровля циклита «В»: как уже было описано выше, результаты корреляции по литологическому признаку в большинстве скважин хорошо согласуются с данными по средней кривой АПс.

Результаты разделения пласта ПК 1-3 на циклиты показаны на рис. 2 [1, 3].

Предположительно отложения начали формироваться за счет деятельности мощной системы меандрирующей реки, наблюдаемой в интервале циклита «С». Затем меандрирующая система сменяется на обстановку дельтовой равнины, что диагностируется в интервале циклита «В».
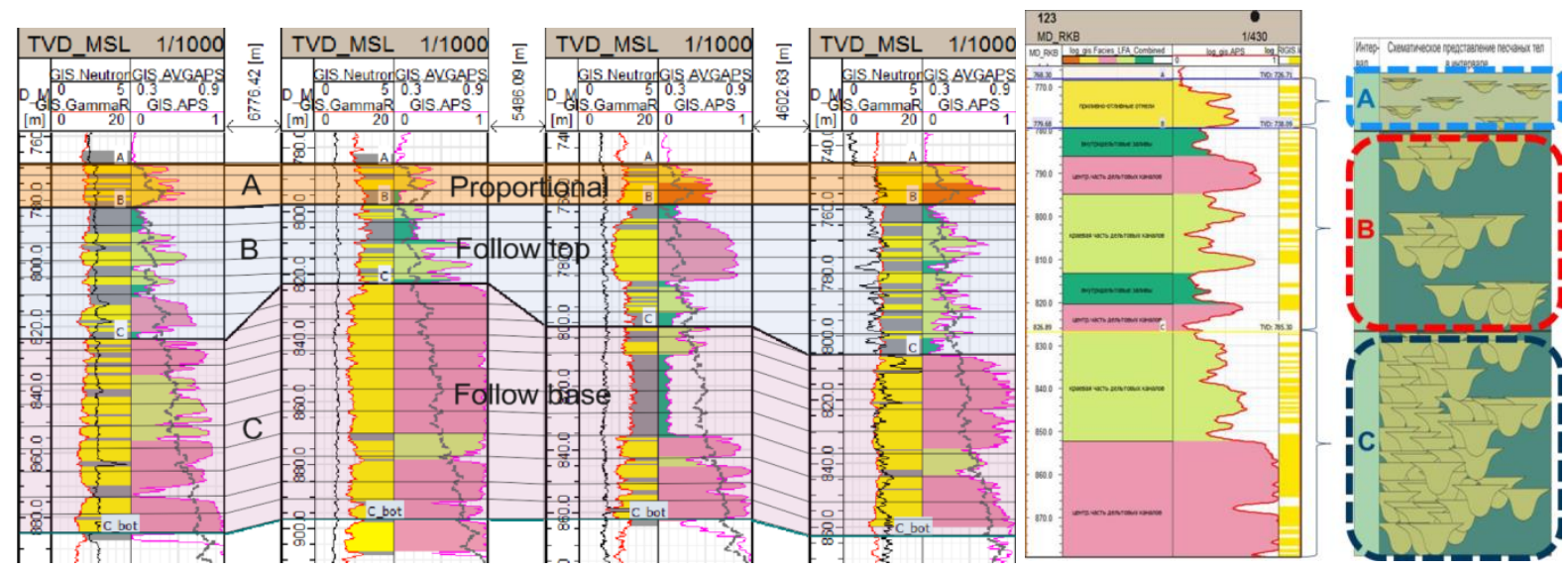

Рис. 2. Разделение пласта ПК 1-3 на циклиты

Fig. 2. Division of PK 1-3 reservoir on cyclets

При этом, если в интервале циклита «В» в дельте превалируют флювиальные процессы (влияние континента), к моменту образования отложений циклита «А» доминирующая роль переходит к приливноотливным процессам - влияние моря.

\section{Выделение ассоциаций фаций}

\section{и их геолого-физическая характеристика}

В модифицированной форме отложения пласта ПК1-3 представлены следующими ассоциациями фаций:

1) приливно-отливная отмель;

2) приливно-отливная гряда;

3) краевая часть дельтовых каналов/краевая часть пояса меандрирования;

4) центральная часть дельтовых каналов/центральная часть пояса меандрирования;

5) внутридельтовый залив/временно заливаемый участк поймы [4-10].

Исходя из сопоставления коэффициента пористости с остаточной водонасыщенностью, пласт ПК1-3 охарактеризован керном довольно равномерно.

Коллекторы с меньшей остаточной водонасыщенностью обладают высокой пористостью, что соответствует теоретическим представлениям. Такая ситуация характерна для пластов, в которых основной параметр, контролирующий фильтрационные и емкостные свойства, - это распределение и количество глинистого материала.

Практически для всех отложений наблюдается большой радиус разлета точек, что свидетельствует об их неоднородности и различной степени консолидированности. Уменьшение фильтрационных свойств в основном связано с уплотнением и вторичными процессами.

Лучшие фильтрационно-емкостные свойства приурочены к ассоциациям фаций центральной части дельтовых каналов/пояса меандрирования. Худшие к ассоциациям фаций внутридельтовых заливов/временно заливаемых участков пойм.

Разные ассоциации фаций характеризуются единой зависимостью коэффициента пористости (Кп)-АПс, детализация их для каждой ассоциации фаций затруднительна. Использование остальных методов для установления количественных критериев «коллекторнеколлектор» и уточнения ФЕС раздельно для каждой фации пласта ПК1-3 недостаточно эффективно за счет влияния газонасыщенности, кавернозности ствола скважины в зоне неконсолидированных отложений, слабой дифференцированности кривых радиоактивного каротажа из-за большого диаметра скважин.

Как было отмечено ранее, для пласта ПК1-3 характерна цикличность и ухудшение фильтрационноемкостных свойств вверх по разрезу. По результатам построения концептуальной модели пласта $[1,3]$, для каждого циклита - «А», «В» и «С» - было выделено от двух до трех типовых разрезов скважин, согласующихся с ассоциациями фаций.

Фильтрационные емкостные свойства и геологофизическая характеристика выделенных типовых разрезов по циклитам пласта ПК1-3 представлены на рис. 3, 4. 


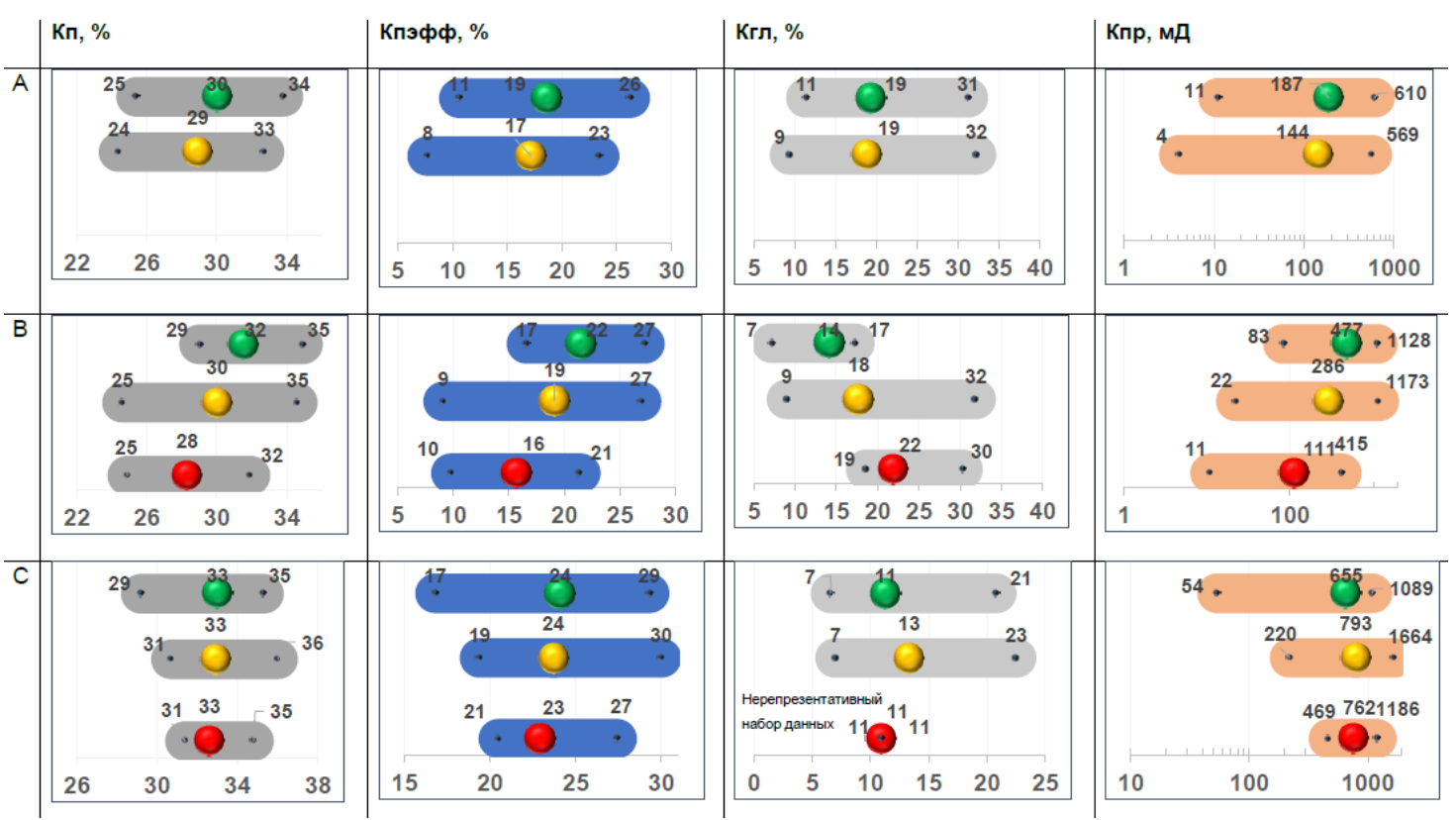

Рис. 3. Фильтрациионное-емкостные свойства типовых разрезов по ичиклитам

Fig. 3. Poro-permeability properties of typical well cross-section for each cyclyte

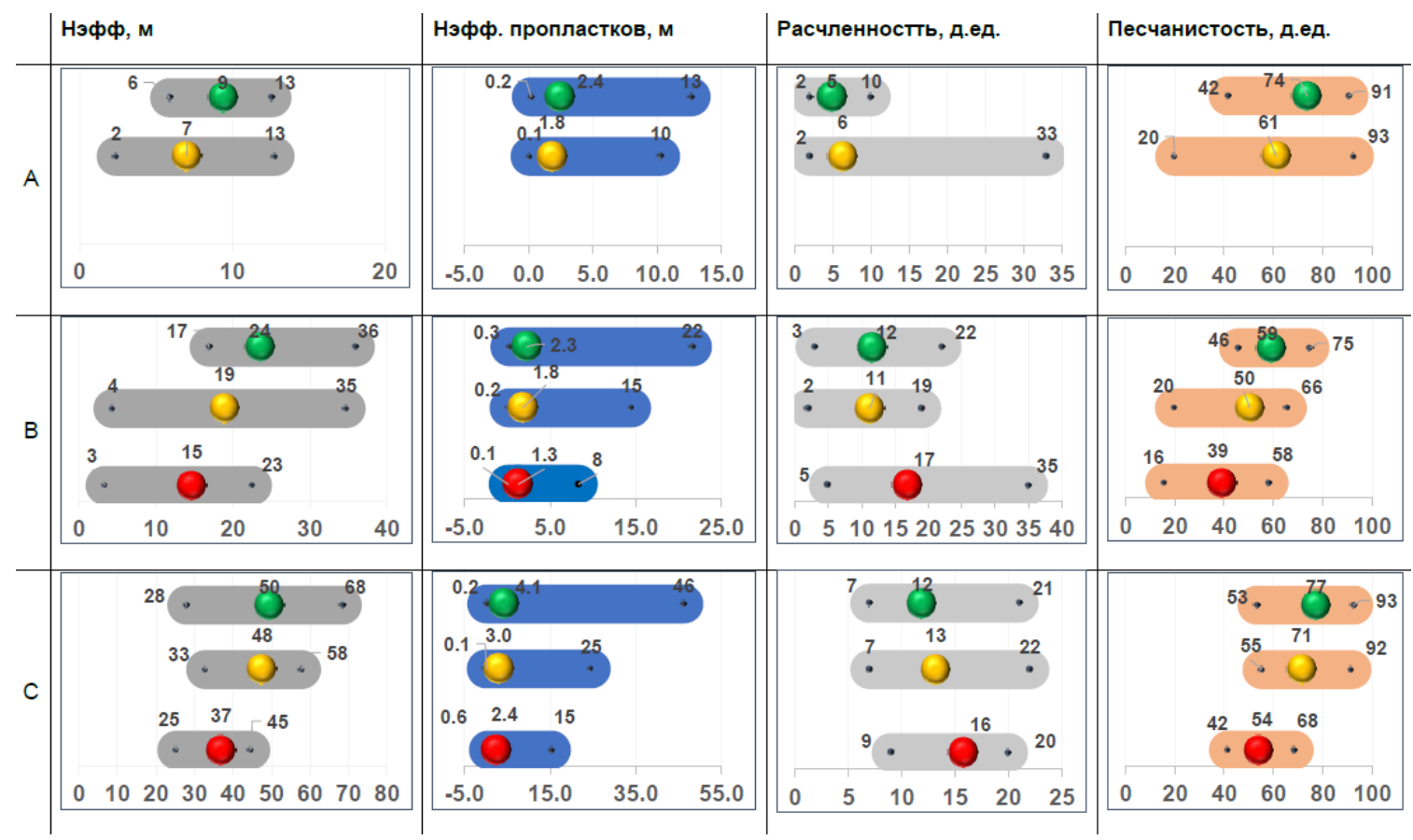

Рис.4. Геолого-физическая характеристика типовых разрезов по ииклитам

Fig. 4. Geology-physical properties of typical well cross-section for each cyclyte

\section{Гранулометрический и минералогический анализ}

По данным гранулометрического анализа все представленные типы разреза имеют приблизительно одинаковую структуру со средним содержанием глинистости около 10-20\%. Во всех разрезах преобладает алевритовая фракция, доля которой может достигать 70-80\%, исключение составляют чистые неглинистые русловые отложения циклита «С», где доля песчаной фракции увеличивается.

Дополнительно были проанализированы суммарные содержания глинистых разностей в пределах каждого цикла. Следует отметить, что состав и со- держание глинистых минералов в пределах каждого петротипа приблизительно одинаковые, также отмечается высокое содержание монтмориллонита и смешанно-слойных образований, которые могут приводить к ухудшению свойств коллектора при взаимодействии с водой.

Как видно из всего вышесказанного, пласт ПК1-3 обладает очень высоким контрастом проницаемостей. Еще одним методом оценки анизотропии пласта является коэффициент Дикстра-Парсона. Суть метода заключается в нахождении коэффициента вариации проницаемости, который определяется статически и 
представляет собой отношение величины стандартного отклонения к математическому ожиданию величины проницаемости [11]. Задача решается графически и находится коэффициент Дикстра-Парсона в диапа- зоне от 0 до 1 , где 0 - гомогенный однородный коллектор, 1 - гетерогенный неоднородный коллектор.

Коэффициент Дикстра-Парсона для типовой скважины ПК 1-3 показан на рис. 5.

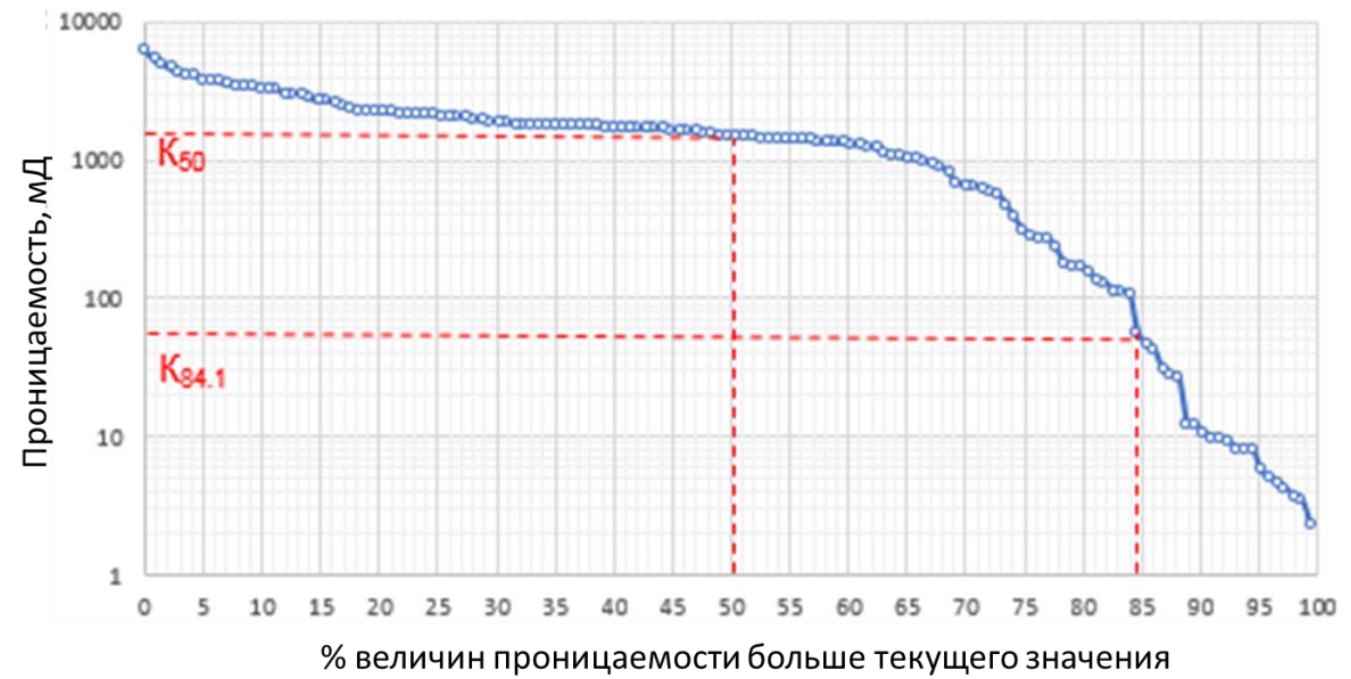

Pис. 5. Графическое определение коэффициента Дикстра-Парсона для типовой скважины

Fig. 5. Graphical definition of the Dyxtra Parsons coefficient for a typical well

Таким образом, для типовой скважины пласта ПК 1-3 коэффициент Дикстра-Парсона составляет 0,9, что еще раз подтверждает высокую неоднородность и гетерогенность коллектора.

\section{Анализ положения контактов и градиентов давлений}

В процессе анализа установлена зависимость положения уровня водонефтяного контакта (ВНК) от кровли циклита «В». Такая же зависимость установлена и для положения зеркала чистой воды (уровня нулевого капиллярного давления), подобранного для каждой скважины путем настройки расчета водонасыщенности по капиллярной модели к результатам расчета по данным геофизических исследований скважин. Такое поведение зеркала свободной воды и водонефтяного контакта является подтверждением наклонности водонефтяного контакта и может свидетельствовать о теории активной законтурной области. Для ее верификации выполнен анализ данных испытаний с применением прибора MDT (modular formation dynamics tester). Для залежей с активным напором в законтурной области характерно присутствие разных градиентов давлений в водяной части залежи, хотя, учитывая высокую плотность нефти, присутствие данного градиента может отличаться очень незначительно. На рис. 6 приведен график зависимости пластового давления от глубины по данным MDT.

На графике видно, что все скважины обладают единым градиентом в водонасыщенной части пласта ПК1-3, что указывает на единое динамическом состояние залежи. Поэтому в данном случае изменение уровня ВНК скорее обусловлено преобладанием первой (неотектонической) гипотезы формирования.

На основании выполненной работы текущее представление о геологическом строении отложений цик- литов пласта ПК1-3 можно описать следующими тезисами:

- разрез пласта ПК1-3 состоит из трех интервалов (трех циклитов), разделенных литологическими границами;

- тектонические нарушения в пределах месторождения имеют преимущественно субмеридиональное простирание;

- между циклитами «А» и «В» есть зоны гидродинамической связи/разобщенности;

- циклиты «В» и «С» являются единым гидродинамически связанным объектом;

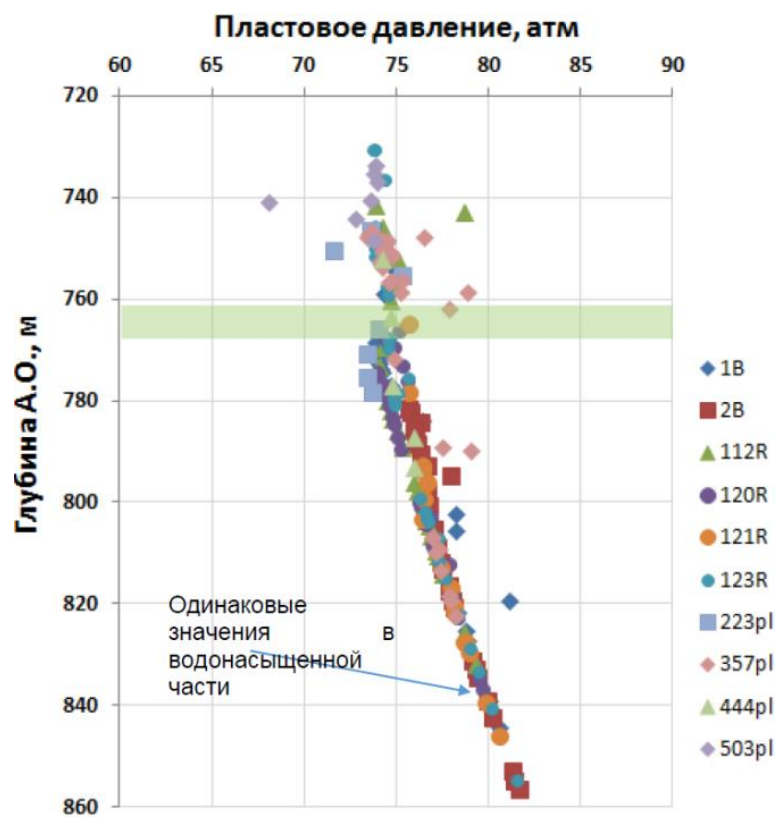

Puc. 6. Градиенты давлений по данным MDT

Fig. 6. Pressure gradients according to MDT 
- в интервале отложений циклита «В» присутствует фациальная зональность, обуславливающая различное положение уровней флюидальных контактов и различную картину по разрезу скважин;

- отложения циклита «С» наиболее выдержаны по площади и по разрезу;

- в пределах сектора первоочередного бурения положение ВНК циклитов «В+С» изменяется в зависимости от структуры в интервале от $-809,3$ м в купольной части до $-819,8$ м в краевой.

\section{Анализ физико-химических свойства нефти и газа}

Относительный фазовые проницаемости в системе «нефрть-вода»

Физико-химические свойства пластовых флюидов Восточно-Мессояхского месторождения изучались по данным исследования поверхностных и глубинных проб. Результаты лабораторных исследований глубинных проб пластовой нефти характеризуются широким диапазоном изменения ее свойств. Основная причина предельно насыщенная нефть на ГНК, вследствие чего при создании даже небольшой депрессии отбор проб производится в условиях двухфазного потока. Свойства физической модели предельно насыщенной нефти соответствуют свойствам, полученным в результате расчетов на основе частично дегазированных, глубинных проб нефти, что подтверждает корректность математических методов оценки свойств пластовой нефти в условиях двухфазной залежи с использованием результатов лабораторных исследований частично дегазированных глубинных проб нефти. Основные физикохимические свойства пластовых флюидов ПК1-3 представлены в таблице и на рис. 7.

Таблица. Основные физико-химические свойства пластовых флюидов ПК1-3

Table. $\quad$ Main properties of reservoir fluids PK 1-3

\begin{tabular}{|l|c|}
\hline \multicolumn{1}{|c|}{ Параметр/Parameter } & $\begin{array}{c}\text { Значение } \\
\text { Value }\end{array}$ \\
\hline Давление насыщения, атм/Bubble point pressure, atm & 78 \\
\hline $\begin{array}{l}\text { Динамическая вязкость пластовой нефти, сПз } \\
\text { Dynamic viscosity, cP }\end{array}$ & 111 \\
\hline Газосодержание, $\mathrm{m}^{3} / \mathrm{m}^{3} / \mathrm{Gas}-$ oil ratio, $\mathrm{m}^{3} / \mathrm{m}^{3}$ & 27,4 \\
\hline $\begin{array}{l}\text { Объемный коэффициент нефти, д. ед. } \\
\text { Formation volume factor, dimensionless }\end{array}$ & 1,045 \\
\hline Плотность нефти, кг $/ \mathrm{m}^{3} /$ Oil density, $\mathrm{kg} / \mathrm{m}^{3}$ & 945 \\
\hline Пластовая температура/Reservoir temperature, ${ }^{\circ} \mathrm{C}$ & 16 \\
\hline
\end{tabular}

Для получения обобщенной кривой относительных фазовых проницаемостей (ОФП) в системе «нефть-вода» проводилась следующая процедура:

1. Полученные в результате лабораторных экспериментов кривые масштабировались от 0 до 1.

2. Масштабированные кривые осреднялись посредством подбора корреляции Corey путем минимизации среднеквадратичной ошибки.

3. Полученные корреляционные кривые масштабировались на средние значения концевых точек исходных лабораторных кривых, полученные результаты показаны на рис. 8 .

По результату исследования значение ОФП воды при остаточной нефтенасыщенности составляет
0,045, что является крайне низким. Для уточнения был изучен мировой опыт определения ОФП на месторождениях-аналогах. Неопределенность в нахождении ОФП в слабоконсолидированных коллеторах с вязкой нефтью явялется очень распростаненной проблемой $[12,13]$. В работе [14] был произведен бенчмаркинг 54 месторождений. Из данного анализа видно, что значения ОФП воды при остаточной нефтенасыщенности изменяются в диапазоне $0,05-0,3$ со занчением Р50 0,13.
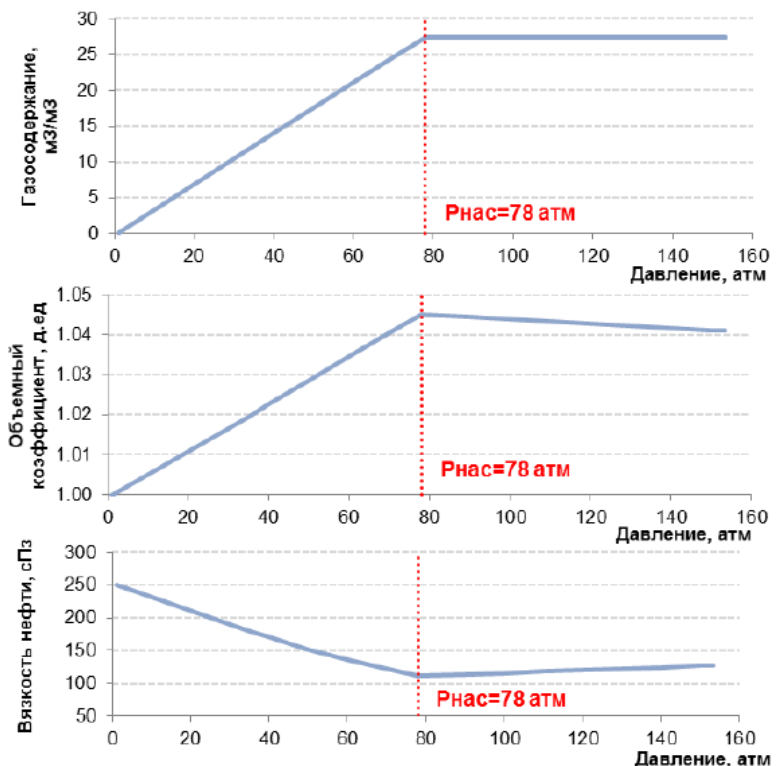

Puc. 7. Основные свойства нефти

Fig. 7. Main oil properties

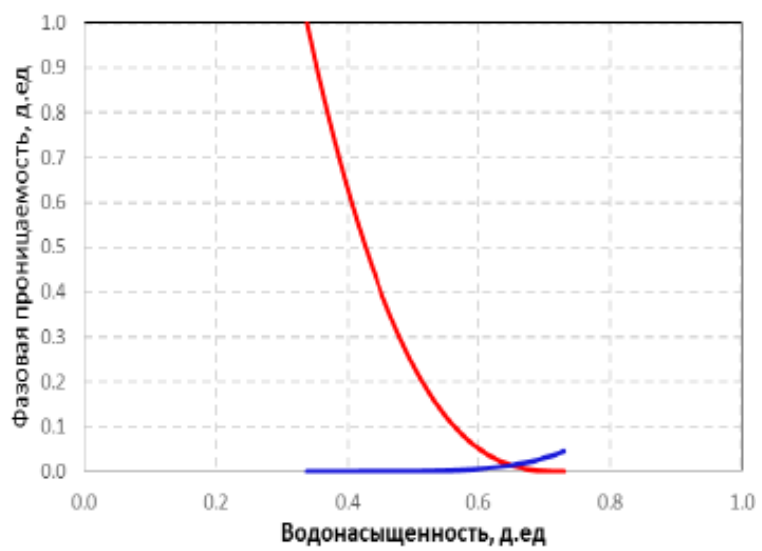

Рис. 8. Относительные фазовые проницаемости в системе «нефть-вода»

Fig. 8. Oil-water releative permeabilities

Исходя из анализа мирового опыта, на начальном этапе разработки было понимание о диапазоне возможных значений ОФП воды при остаточной нефтенасыщенности и важности данного параметра. Ввиду отсутствия истории добычи было выбрано верхнее значение, равное 0,3. По мере накопления истории разработки и адаптации модели данное занчение было скорректировано до 0,15, и есть понимание, что это не окончательное значение. Таким образом, величина соотношения подвижностей М, расчитанного по 
концевым точкам ОФП, составляет от 5 до 30 и оказывает существенное влияние на эффективность разработки пласта ПК1-3.

\section{Относительные фазовые проницаемости}

в системе «нефть-газ»

По месторождениям-аналогам высоковязкой нефти (Канада и США) в среднем при достижении газонасыщенности 33 \% эффективного порового пространства подвижность по нефти становится нулевой. Учитывая остаточную водонасыщенность по пласту ПК1-3, которая составляет 37 \%, значение остаточной нефтенасыщенности (SOGCR) при вытеснении газом составит 30 \%. Значение ОФП по газу при остаточной нефтенасыщенности также принято согласно мировому опыту и составляет 0,4 (рис. 9).

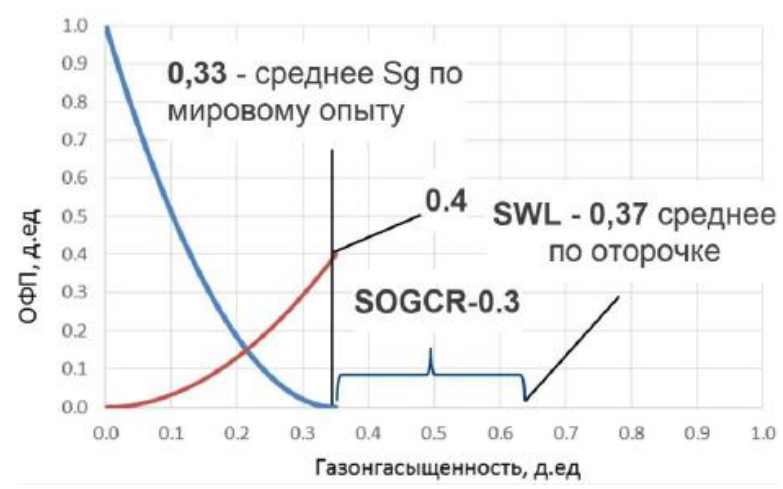

Рис. 9. Относительные фазовые проницаемостив системе «нефть-газ»

Fig. 9. Oil-gas releative permeabilities

\section{Остаточная водонасыщенность}

На основании имеющихся данных по капиллярометрическим исследованиям образцов керна построена зависимость остаточной водонасыщенности от керновой пористости (рис. 10).

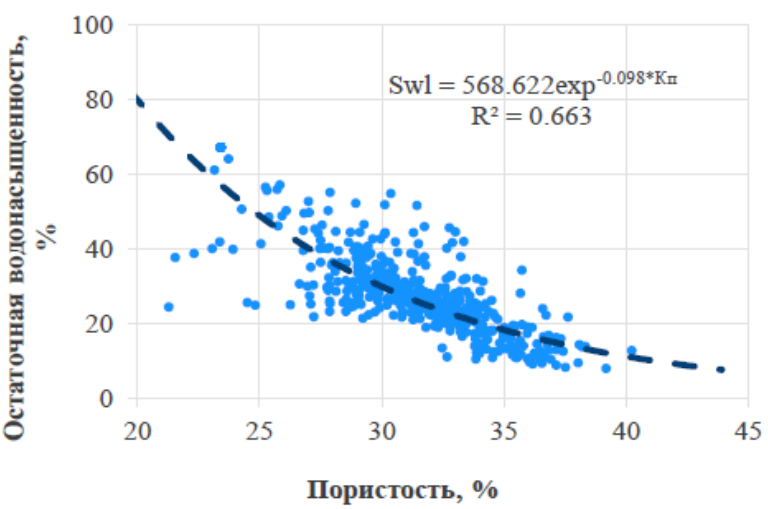

Pис. 10. Зависимость остаточной водонасыщенности от пористости

Fig. 10. Relation between residual water saturation and porosity

\section{Критическая водонасыщенность}

На следующем этапе актуализировалась на новые данные зависимость для критической водонасыщенности (SWCR). Были проанализированы зависимости
SWCR от пористости, абсолютной проницаемости и остаточной водонасыщенности. Наибольшую сходимость показала линейная зависимость критической водонасыщенности от остаточной, которая была выбрана для дальнейшего использования (рис. 11).

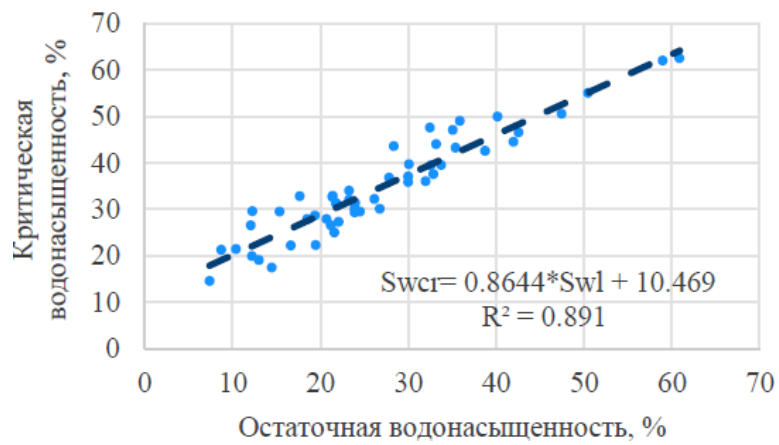

Puc. 11. Зависимость критической водонасыщенности от остаточной

Fig. 11. Relation between residual and critial water saturation

\section{Остаточная нефтенасыщенность}

при вытеснении нефти водой

При анализе данных учитывались результаты экспериментов как по определению ОФП, так и по определению остаточной нефтенасыщенности и коэффициента вытеснения нефти водой. На рис. 12 отражено сопоставление замеров остаточной нефтенасыщенности при вытеснении нефти водой от пористости.

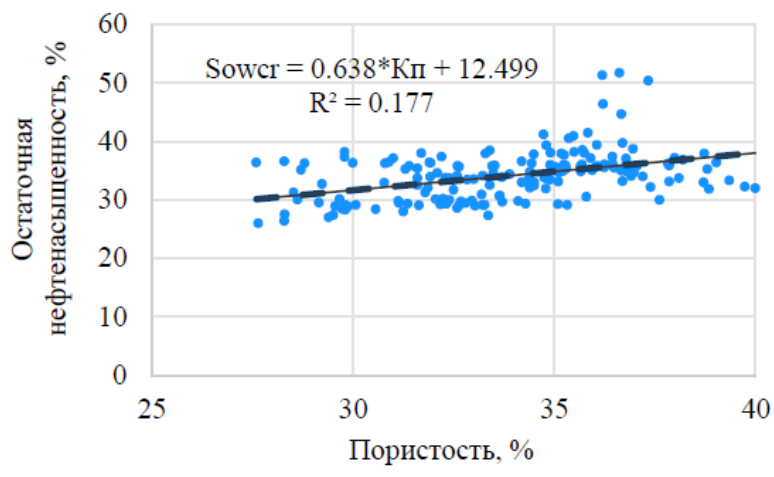

Pис. 12. Зависимость остаточной нефтенасыщенности от пористости

Fig. 12. Relation between residual oil saturation and porosity

B связи с тем, что ярко выраженной корреляции SOWCR от ФEC не наблюдается, принято среднее значение остаточной нефтенасыщенности с учетом поведения тренда по результатам исследований крена. При средней пористости пласта ПК1-3 SOWCR составляет $31 \%$.

\section{Критическая газонасыщенность}

Проведен ряд экспериментов по определению критической газонасыщенности (SGCR), при этом стоит отметить, что существующие методики измерения не позволяют корректно определить точку начала движения газа при значениях газонасыщенности. Но если провести экстраполяцию данных на примере одной из скважин, получаем нулевое значение SGCR. B усло- 
виях большой разности вязкостей (нефть - 111 сП, газ - 0,013 сПз) возникает большая разность подвижностей фаз.

Поэтому справедливо полагать, что для растворенного газа, выделившегося из нефти, действует правило гистерезиса ОФП по Коутсу [15]. В данной модели описан гистерезис кривых в системе «нефтьгаз» при присутствии критической воды и критической нефти. В системе «нефть-газ» нефть является смачивающим флюидом, газ не смачивающим. Так, при снижении пластового давления происходит появление первых пузырьков газа. Дальнейшее изменение кривой ОФП по газу проходит по так называемой кривой вытеснения. Данная кривая справедлива для того случая, когда вытеснение происходит полностью, до получения критического значения насыщенности по нефти (точка Krgro). Обратный процесс, так называемая капиллярная пропитка, пойдет по кривой 2 и дойдет до значения критической газонасыщенности. Далее при обратном вытеснении возникает новая критическая газонасыщенность (Sgs*), которая значительно ниже значения при полном вытеснении (Sgs).

В соответствии с этим критическая газонасыщенность была посчитана по кривой вытеснения. По расчетам получено околонулевое значение критической газонасыщенности в нефтяной оторочке. Таким образом, в нефтяной оторочке значение SGCR принято равным 0 .

\section{Исследование геомеханических свойств пласта ПК1-3}

Для интерпретации ослабленных плоскостей пласта ПК1-3 (поверхности, вдоль которых действует наибольшее отношение касательного к нормальному напряжению, практически отсутствует когезия и низкий коэффициент угла внутреннего трения, данные поверхности также характеризуются аномалией по сейсмическим атрибутам) использовалась технология Ant Tracking.

На рис. 13, А показана результирующая карта разрывных нарушений, построенная по данным атрибута Ant Tracking, на рис. 13, Б - карта разрывных нарушений по концептуальной геологической модели [16]. Можно отметить, что дислокации по второй карте прослеживаются с высокой точностью на первой карте, но также наблюдается и обратная связь. Ряд разрывов закартированы только при первом подходе к интерпретации. Анализируя возможный структурный парагенез, однозначно можно сказать, что на Восточно-Мессояхском месторождении сочетаются зоны сжатия, сдвига и растяжения.
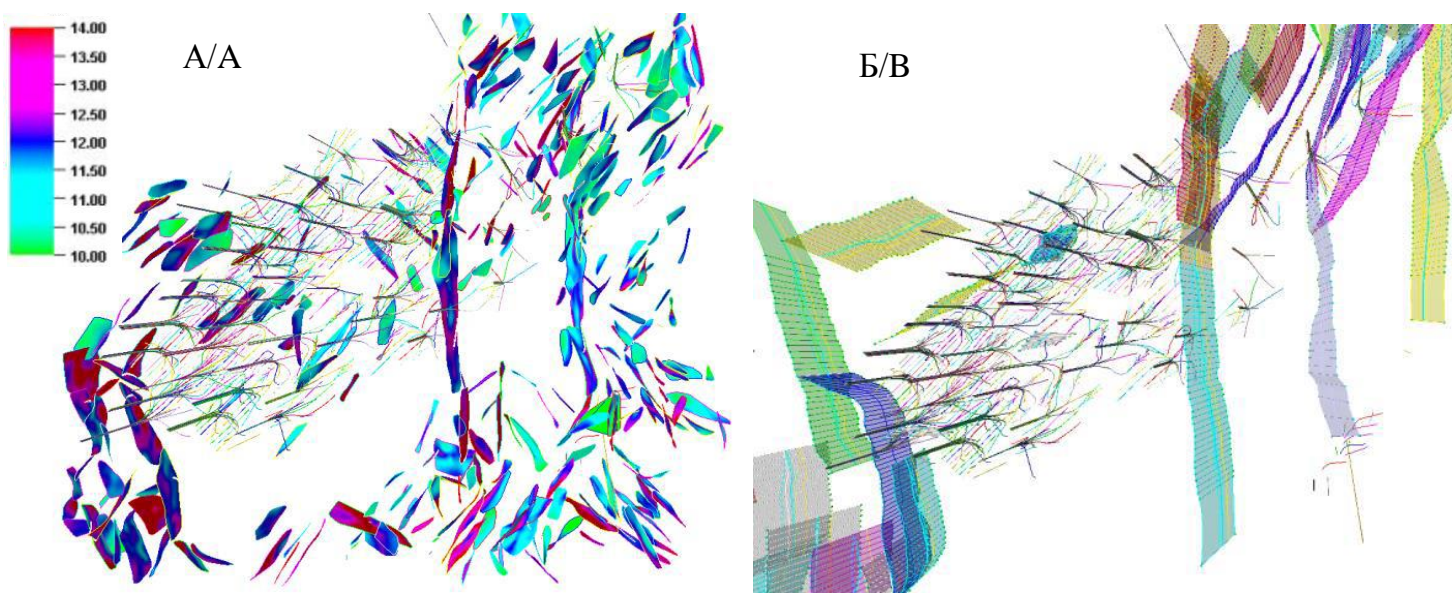

Puc. 13. Структурные формы - дислокации, выделенные по атрибуту Ant Tracking (A) и разрывные нарушения из концептуальной геологической модели (Б)

Fig. 13. Structural forms allocated by Ant Tracking attribute (A) and discontinuities from the conceptual geological model (B)

При сравнении полученных результатов с типовыми парагенезами тектонических нарушений по Л.М. Расцветаеву можно сделать вывод, что «елочка» (номер VII) и карта, построенная на основе первого подхода, в целом лучше всего описывают тектоническую обстановку региона и структурный парагенез.

Формирование разрывов сплошности в горной породе может быть связано с двумя процессами: формированием пликативной структуры и дизъюнктивного разрывного нарушения. На палетке типовых парагенезов тектонических нарушений по Л.М. Расцветаеву представлены те парагенезы, которые связаны с хрупким разрушением пород. Складкообразование же является следствием пластического деформирования горных пород, их «течения» в геологическом масштабе. Во время складкообразования также происходит хрупкое разрушение, но в более мелком масштабе разрывы возникают в тех местах, где действующие напряжения превышают предел прочности породы, силы внутреннего трения и сцепления. Традиционно формирование крупного разрыва сопряжено с образованием множества микроразрывов по будущей поверхности разрушения - скольжения. Модель образования складки поперечного изгиба, вероятно, соответствует положительной структуре ВосточноМессояхского месторождения [17].

Во время образования положительной структуры (складкообразования) формировались разрывы, сонаправленные со складками, образование которых связано с действием растягивающего напряжения в ортогональном направлении. На крыльях наблюдаются разрывы, которые возникли за счет действия сдвиго- 
вых напряжений, плоскости ориентированы под углом к изолиниям структурной карты, локализованы в основном в южном крыле.

После складкообразования начали действовать «деструктивные» тектонические силы, которые привели к хрупкому разрушению пород. В ходе этого этапа сформировались основные разрывные нарушения, включая зону грабена, которая сопряжена двумя сдвиго-сбросами. Как было указано ранее, на данном месторождении по морфологии разрывных нарушений и информации по структурной карте (перемещения) сделан вывод о том, что в бассейне действовал структурный парагенез типа «елка» по Л.М. Расцветаеву с формированием трех зон: сжатия, растяжения и сдвига.
Далее по выявленным ослабленным плоскостям (разрывам и литологическим границам) был проведен расчет критически напряженного состояния на основе трехмерной геомеханической модели [18]. В результате данного расчета разрывы разделены на два типа: критически напряженные - активные, и критически не напряженные - пассивные (рис. 14). Активные дислокации интересны с точки зрения бурения (в данных областях могут наблюдаться поглощения) и большой вынос твердых частиц. Для проведения такого расчета используется линейный критерий разрушения Мора Кулона с допущением: когезия по разрыву = 0 МПа, коэффициент угла внутреннего трения 21 градус.
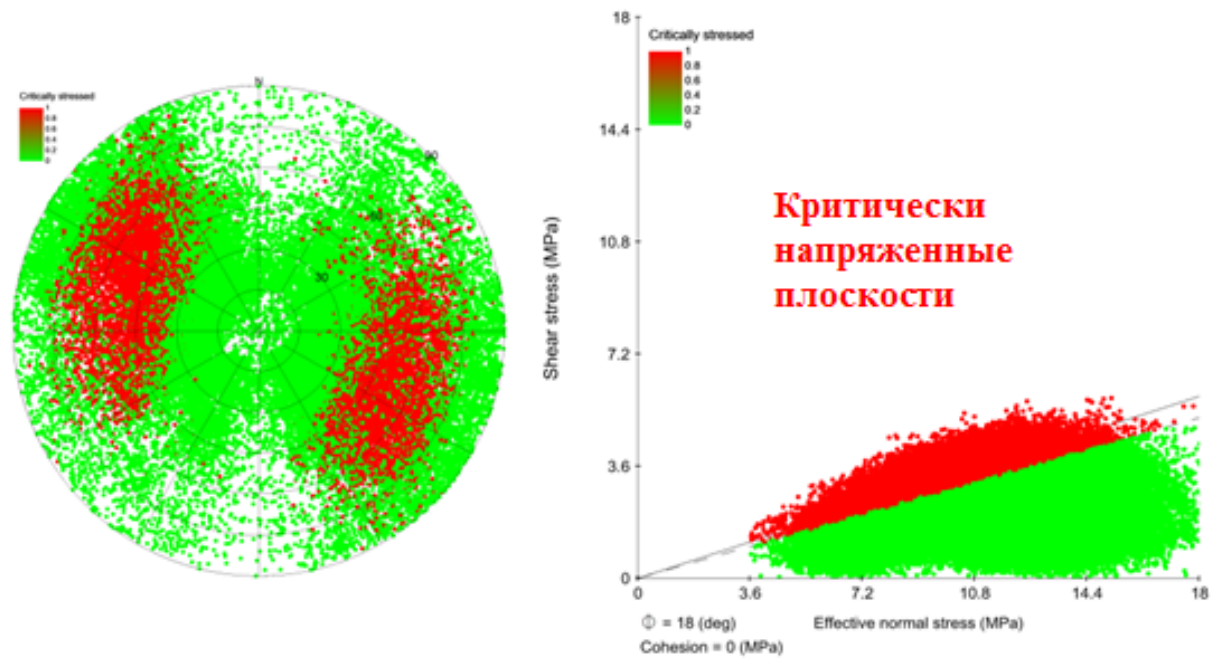

Критически не напряженные плоскости

Рис. 14. Диаграммы критически напряженного состояния естественных ослабленных плоскостей. Красные - критически напряженные плоскости, зеленые - не критически напряженные

Fig. 14. Charts of the critical state of natural weakened planes. Red is critical, green is not critical

Можно отметить, что 25-30 \% из всех участков плоскостей (плоскости отражены точками с определенном шагом дискретизации) являются «активными», бурение через активные плоскости увеличивает риск осложнений при бурении скважин и накладывыает определенные риски при разработке.

\section{Анализ работы аквифера}

\section{и оценка его влияния на режим разработки}

Еще одной особенностью пласта ПК1-3 является наличие подстилающего водоносного горизонта (аквифера), имеющего гидродинаимческую связь различной степени с циклитом «С».

Для оценки параметров аквифера была использована концепция материального баланса [19]. Для описания аквифера была использована аналитическая модель аквифера Фетковича, позволяющая оценить приток из аквифера, его размер и продуктивность, основываясь на фактических объемах добычи/закачки путем адаптации пластового давления. Помимо этого, был рассчитан вклад каждого режима разработки, также с применением материального баланса, полученные результаты по блокам с заводнением показаны на рис. 15 [3].
На различных участках параметры аквифера сущесвенно различаются и он оказывает различный вклад в режим разработки. Продуктивность аквифера изменяется от 20 до $1250 \mathrm{~m}^{3} /$ сут/атм, вклад аквифера в компенсацию составляет от 18-67 \%. Тем не менее даже в участках с самым продуктивным и активным аквифером, несмотря на присутствие режима растворенного газа, пластовое давление интенсивно снижается, что говорит о необходимости своевременного примененя вторичных методов разработки для поддержания пластового давления.

Также необходимо понимать, что энергия аквифера ограничена и важно не допускать снижения пластового давления в аквифере путем своевременной организации закачки/ограничении отборов, что особенно важно для месторождений вязкой нефти [20]. По факту имеющейся истории разработки пласта ПК1-3 даже участки с очень высокопродуктивным аквифером подвержены снижению пластового давления, особенно при хорошей гидродинамической связи и наличии конусов. Это говорит о необходимости своевременной организации системы поддержания пластового давления с правильно выбранным агентом вытеснения, учитывающим все описанные выше особенности пласта ПК 1-3. 

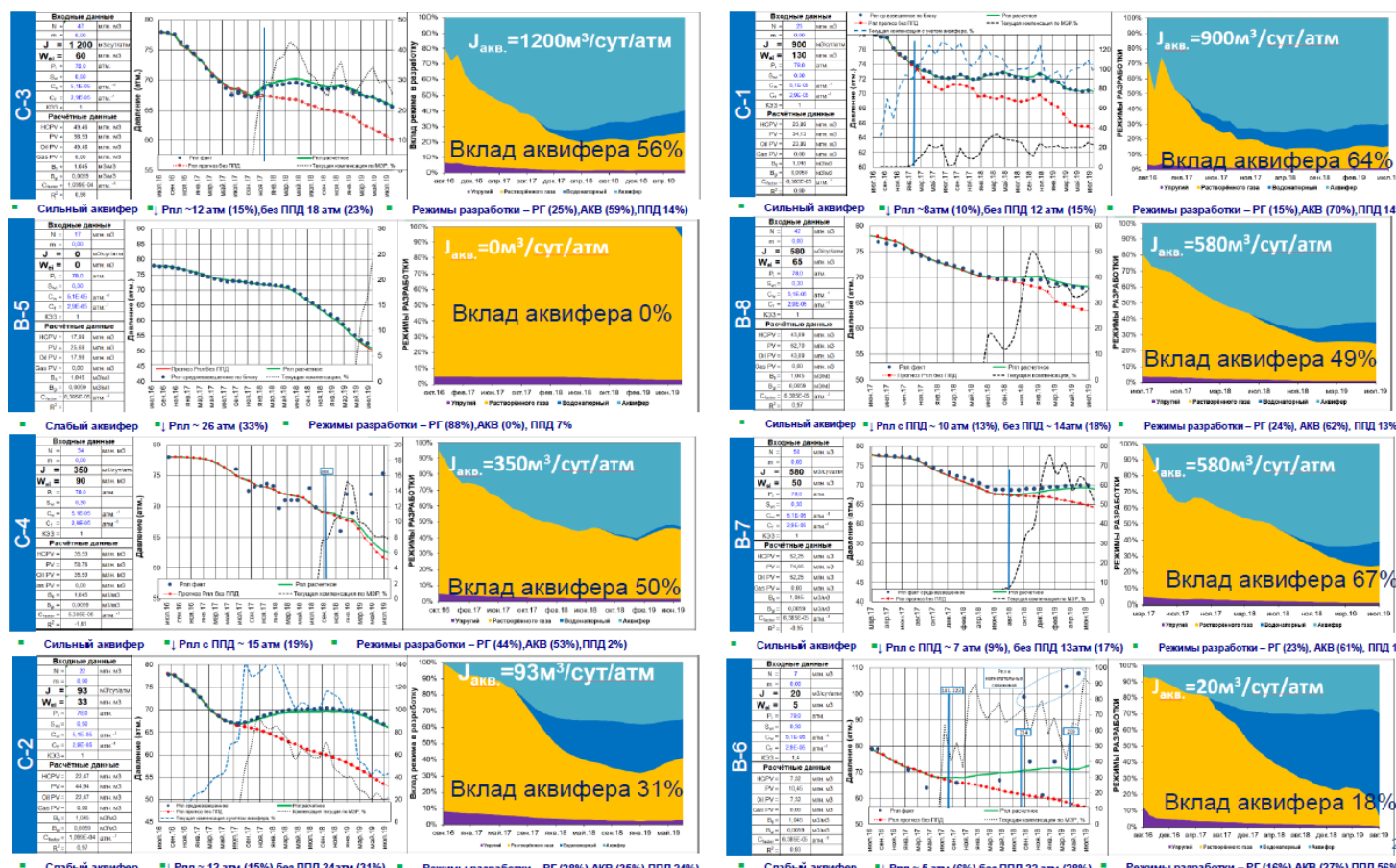

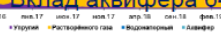
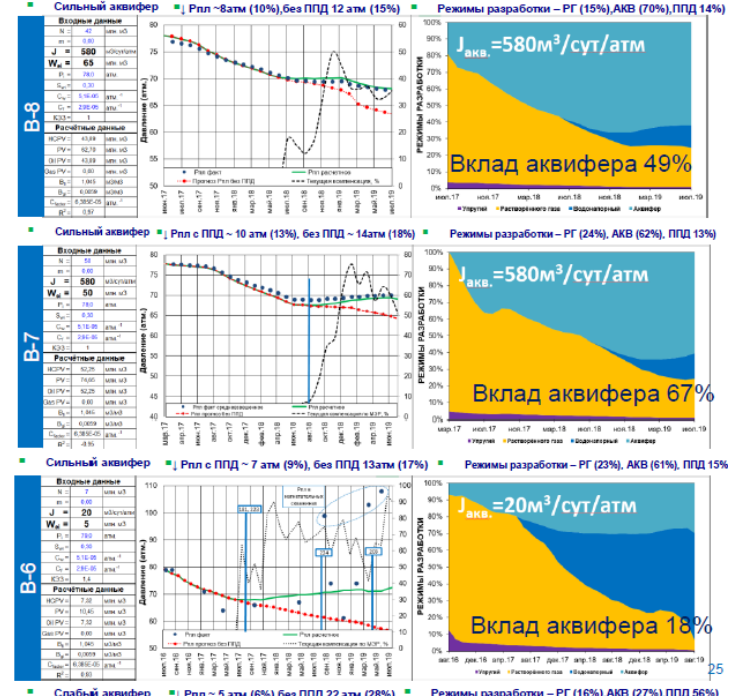

Pис. 15. Результаты оценки параметров аквифера и режимов разработки по блокам

Fig. 15. Results of estimation of the aquefer parameters and block drive indexes calculation

\section{Заключение}

Исследование ключевых геологофизических характеристик слабоконсолидированного коллектора вязкой нефти ПК 1-3 и его флюидов позволило выделить основные особенности, важные для его эффективной разработки:

- континентальные отложения с преобладанием русловых и пойменных фаций;

- слабоконсолидированный коллектор;

- высокая неоднородность и расчленённость коллектора;

- наличие пропластков с различной степенью гидродинамической связанности;

- высоковязкая нефть и неблагоприятное соотношение подвижностей;

- высокое содержание глинистой составляющей;

- низкая пластовая температура;

- наличие геомеханических эффектов и ослабленных естественных плоскостей;

\section{СПИСОК ЛИТЕРАТУРЫ}

1. Обновление концептуальной геологической модели пласта ПК1-3 Восточно-Мессояхского месторождения: отчет о НИР Б.В. Белозеров, Б.В. Буторин, Д.А. Решетников, А.О. Вайсман, Р.3. Фаизов, Н.А. Парфенов. - Тюмень: ООО «Газпромнефть НТЦ», 2016 г. - 164 c.

2. Зундэ Д.А., Попов И.П. Методика построения сиквенсстратиграфической модели покурской свиты // Нефтепромысловое дело. - 2015. - № 5. - С. 54-59.

3. Заводнение Восточно-Мессояхского месторождения с высоковязкой нефтью в слабоконсолидированном коллекторе - вызовы и проактивность / И.Р. Ильясов, А.А. Подкорытов, А.А. Гудз, В.С. Комаров, Н.А. Глущенко // SPE-196752-RU. - 2019. - C. 5-10. URL https://doi.org/10.2118/196752-MS (дата обращения 04.08.2020).

4. Барабошкин Е.Ю. Практическая седиментология. Терригенные резервуары: пособие по работе с керном. - Тверь: ГЕРС, 2011. $-152 \mathrm{c}$.
- наличие растворенного газа и аквифера с различной продуктивностью;

- интенсивное снижение пластового давления, невозможность разработки на истощении.

Таким образом, очевидна необходимость применения вторичных методов разработки и системы поддержания пластового давления. Однако ввиду описанных выше особенностей заводнение пласта ПК 1-3 сопряжено с высокими рисками прорывов воды и низким коэффициентом охвата пласта заводнением, что будет оказывать большое влияние на эффективность разработки пласта ПК 1-3 и конечный коэффициент извлечения нефти. Поэтому исследование возможности применения альтернативных технологий и агентов заводнения слабоконсолидированных коллекторов вязкой нефти, в том числе с применением физико-химических методов увлечения нефтеотдачи с системным подходом, является актуальной и интересной задачей.

5. Филиппович Ю.В., Захарова О.А., Чухланцева Е.Р. Литологофациальный анализ по основным резервуарам юры и мела Восточно-Мессояхского и Западно-Мессояхского месторождений: отчет о НИР. - СПб.: ООО «Газпром нефть НТЦ», 2011. $-172 \mathrm{c}$.

6. Einsele G. Sedimentary basins: evolution, facies, and sediment budget. - Berlin; Heidelberg: Springer, 1992. - 628 p.

7. Selley R. Applied sedimentology. 2nd ed. - London: Academic Press, 2000. $-523 \mathrm{p}$.

8. Sedimentary facies computation and stratigraphic analyses using well logs, borehole images and cores in triassic fluvial sandstones of the Algerian Sahara / T. Ogunyemi, P. Montaggioni, I. Boubakeur, M. Junguito, M. Batrina // SPE-121945-MS. 2009. - C. 4-11. URL: https://doi.org/10.2118/121945-MS (дата обращения 04.08.2020)

9. Особенности геологического строения и нефтегазоносность Среднемессояхского вала / С.Е. Агалаков, А.Н. Бабурин, 
С.Н. Беспалова, В.С. Бочкарев, И.О. Коровина // Горные ведомости. Тюмень. - 2004. - № 1. - С. 48-72.

10. Нейман В.Б. Теория и методика палеотектонического анализа. - М.: Недра, 1974. - 79 с.

11. Statistics for petroleum engineers and geoscientists / J.L. Jensen, L.W. Lake, P.W.M. Corbett, D.J. Goggin. - New Jersey: Prentice Hall PTR, 1997. -390 p.

12. Wang J., Dong M., Ashghari K. Effect of oil viscosity on heavy oil-water relative permeability curves // SPE-99763-MS. - 2006. C. 3-8. URL: https://doi.org/10.2118/99763-MS (дата обращения 04.08.2020).

13. Elhaj M., Hashan M., Hossain M. A critical review and future trend on relative permeability hysteresis // SPE-191260-MS. 2018. - C. 5-8. URL: https://doi.org/10.2118/191260-MS (дата обращения 04.08.2020).

14. Berg E.A, Bjorlykke O.P. Heavy oil and relative permeability in laboratory, simulations and production. Is there a link? // SPE172856-MS. - 2014. - C. 2-4. URL: https://doi.org/10.2118/172856MS (дата обращения 04.08.2020).
15. Азиз Х., Сеттари Э. Математическое моделирование пластовых систем / пер. с англ. 2-е изд., стер. - М.: Институт компьютерных исследований, 2004. - 407 с.

16. Лукин С.В., Жигульский С.В., Шаповалова А.А. Отчет по геолого-геомеханическому моделированию: отчет НИР. - СПб.: ООО «Газпром нефть НТЦ», 2018. - 71 с.

17. Гзовский М.В. Основные вопросы тектонофизики и тектоника Байджансайского антиклинория. - М.: АН СССР, 1959. - 255 с

18. Zoback M.D. Reservoir geomechanics. - Cambridge: Cambridge University Press, 2007. - 500 p.

19. Ahmed T. Reservoir engineering handbook third edition. Burlington: Gulf professional publishing, 2005. - $1377 \mathrm{p}$.

20. Successful strategy for waterflooding project implementation in an extra heavy oil field / L. Nino, F. Bonilla, L. Gil, W. Henao, J. Reina, E. Jimenez, P. Vivas // SPE-198924-MS. - 2020. - C. 5-9. URL: https://doi.org/10.2118/198924-MS (дата обращения 04.08.2020)

Поступила: 09.07.2020 2.

\section{Информация об авторах}

Ильясов И.Р., кандидат технических наук, заместитель начальника управления разработки месторождений нефти и газа, Акционерное общество «Мессояханефтегаз».

Грачев С.И., доктор технических наук, профессор, заведующий кафедрой разработки и эксплуатации нефтяных и газовых месторождений Тюменского индустриального университета. 
UDC 622.276

\title{
GEOLOGICAL AND PHYSICAL CHARACTERISTICS OF THE FIELD DEVELOPMENT OF UNCONSOLIDATED VISCOUS OIL RESERVOIRS
}

Ilnur R. llyasov',

ilnur_ilyasov@mail.ru

\author{
Sergey I. Grachev², \\ grachevsi@tyuiu.ru \\ 1 Joint Stock Company «Messoyakhaneftegaz», \\ 8B, 50 let Oktyabrya street, Tyumen, 625048, Russia. \\ 2 Tyumen Industrial University, \\ 70, Melnikaite street, Tyumen, 625000, Russia.
}

The relevance. The East-Messoyakhskoe field is unique not only in terms of geological reserves, but also in its geological characteristics. Main reservoir PK 1-3 contains about $65 \%$ of the reserves and is an unconsolidated reservoir with a high-viscosity oil. There is practically no experience in development of similar oil fields in the Arctic conditions. The study of geological and physical characteristics of unconsolidated reservoirs with viscous oil is a relevant objective.

The main aim of the research is to analyze and identify the key geological and physical characteristics of the field development of unconsolidated viscous oil reservoirs in order to find methods and technologies for improving field development efficiency.

Objects of the research are unconsolidated viscous oil reservoir under development of the East- East-Messoyakhskoe field.

Methods: critical analysis, content analysis, analysis and generalization of existing experience in the development of unconsolidated viscous oil reservoirs on the example of the PK 1-3 reservoir of the East-Messoyakhskoe field.

Results. The authors have carried out the critical analysis of the key geological and physical characteristics of the PK 1-3 reservoir and its fluids research, which must be taken into account in order to develop it with maximum efficiently. The list of key characteristics was made. Their impact on the field development efficiency was shown. The analysis of waterflooding experience and aquifer impact reservoir development was performed. The need for the use of secondary development methods for PK 1-3 reservoir and reservoir pressure maintaining system was proved. However, due to the characteristics described above, the traditional waterflooding of unconsolidated viscous oil reservoirs carries with it high risks of early water breakthrough and poor sweep efficiency, which will have a great impact on the field development efficiency and the final oil recovery factor. It was concluded about the requirement of alternative technologies and flooding agents research, including the application of physico-chemical enhanced oil recovery methods with a systemic approach, which is a relevant and interesting task.

\section{Key words:}

Unconsolidated reservoir, viscous oil, flooding, geological and physical characteristics, field development.

\section{REFERENCES}

1. Belozerov B.V., Butorin B.V., Reshetnikov D.A., Vaisman A.O. Faysov R.Z., Parfenov N.A. Obnovlenie kontseptualnoy geologicheskoy modeli plasta PK1-3 Vostochno-Messoyakhskogo mestorozhdeniya: otchet o NIR [Update of the conceptual geological model of the PK1-3 formation of the East-Messoyakhskoe field: Research report]. Tyumen, Gazpromneft science and technology center, 2016. $164 \mathrm{p}$.

2. Zundae D.A., Popov I.P. Methodology for the construction of the sequence-stratigraphic model of the Pocur suite. Oilfield engineering, 2015, no. 5, pp. 54-59. In Rus.

3. Ilyasov I., Podkorytov A., Gudz A., Komarov V., Glushchenko N. Waterflooding East-Messoyakhskoe heavy oil field in unconsolidated reservoir - challenges and proactivity. SPE-196752-MS, 2019, pp. 5-10. In Rus. available at: https://doi.org/ 10.2118/196752-MS (accessed 4 August 2020).

4. Baraboshkin E.Y. Prakticheskaya sedimentologiya. Terrigennye rezervuary: posobie po rabote s kernom [Practical sedimentology. Clastic reservoirs: core manual]. Tver, GERS Publ., 2011. 152 p.

5. Filippovich Yu.V. Litologo-fatsialny analiz po osnovnym rezervuaram Yury i Mela Vostochno-Messoyakhskogo i ZapadnoMessoyakhskogo mestorozhdeniy: otchet o NIR [Litologo-factorial analysis of the main reservoirs of the Jursic and Cretaceous period of the East- Messoyakhskoe field and West- Messoyakhskoe fields deposits: Research report].Saint Petersburg, Gazpromneft science and technology center, 2011. $172 \mathrm{p}$.

6. Einsele G. Sedimentary basins: evolution, facies, and sediment budget. Berlin, Heidelberg, Springer, 1992. 628 p.

7. Selley R. Applied sedimentology. $2^{\text {nd }}$ ed. London, Academic Press, 2000. 523 p.
8. Ogunyemi T., Montaggioni P., Boubakeur I., Junguito M., Batrina M. Sedimentary facies computation and stratigraphic analyses using well logs, borehole images and cores in triassic fluvial sandstones of the Algerian Sahara. SPE-121945-MS, 2009, pp. 4-11. Available at: https://doi.org/10.2118/121945-MS (accessed $4 \mathrm{Au}-$ gust 2020).

9. Agalakov S.E., Baburin A.N., Bespalova S.N., Bochkarev B.C., Korovina I.O The geological structure and oil bearing features of the Middle Messoyakha shaft. Gornye vedomodsti, 2004, no. 1, pp. 48-72. In Rus.

10. Neiman V.B. Teoriya i metodika paleotektonicheskogo analiza [Theory and methodology of paleotectonic analysis]. Moscow, Nedra Publ., 1974. 79 p.

11. Jensen J.L., Lake L.W., Corbett P.W.M., Goggin, D.J. Statistics for petroleum engineers and geoscientists. New Jersey, Prentice Hall PTR, 1997. $390 \mathrm{p}$

12. Wang J., Dong M., Ashghari K. Effect of oil viscosity on heavy oil-water relative permeability curves. SPE-99763-MS, 2006, pp. 3-8. Available at: https://doi.org/10.2118/99763-MS (accessed 4 August 2020).

13. Elhaj M., Hashan M., Hossain M. A critical review and future trend on relative permeability hysteresis. SPE-191260-MS, 2018, pp. 5-8. Available at: https://doi.org/10.2118/191260-MS (accessed 4 August 2020)

14. Berg E.A, Bjorlykke O.P., Heavy oil and relative permeability in laboratory, simulations and production. Is there a link? SPE172856-MS, 2014, pp. 2-4. Available at: https://doi.org/10.2118/ 172856-MS (accessed 4 August 2020).

15. Aziz X., Settari E. Matematicheskoe modelirovanie plastovykh sistem [Mathematical modeling of reservoir systems]. Translated 
from English. Moscow, Institute of computer research Publ., 2004. $407 \mathrm{p}$.

16. Lukin S.V. Otchet po geologo-geomekhanicheskomu modelirovaniyu: otchet NIR [Geology and geomechanics simulation: Research report]. Saint Petersburg, Gazpromneft science and technology center, 2018. $71 \mathrm{p}$.

17. Gzovskii M.V. Osnovnye voprosy tektonofiziki $i$ tektonika Baydzhansayskogo antiklinoriya [The main techtonophysics and tectonics questions of Baydzhansaysky anticlinorium]. Moscow, AS USSR, 1959. $255 \mathrm{p}$.
18. Zoback M.D. Reservoir geomechanics. Cambridge, Cambridge University Press, 2007. 500 p.

19. Ahmed T. Reservoir engineering handbook. $3^{\text {rd }}$ ed. Burlington, Gulf professional publishing, 2005. $1377 \mathrm{p}$.

20. Nino L., Bonilla F., Gil L., Henao W., Reina J., Jimenez E., Vivas P. Successful strategy for waterflooding project implementation in an extra heavy oil field. SPE-198924-MS, 2020, pp. 5-9. Available at: https://doi.org/10.2118/198924-MS (accessed 4 August 2020).

Received: 9 July 2020.

\section{Information about the authors}

Ilnur R. Ilyasov, Cand. Sc., deputy director, Joint Stock Company «Messoyakhaneftegaz».

Sergey I. Grachev, Dr. Sc., professor, head of the department, Tyumen Industrial University. 